Original Research Paper

\title{
Artikel Ilmiah Sebagai Media Kenaikan Pangkat Guru MA - MTs di Pondok Pesantren Darul Aminin NW Aikmual Praya Lombok Tengah
}

\author{
Dian W. Kurniawidi', Teguh Ardianto' ${ }^{1}$, Syamsuddin' $^{1}$ I Wayan Sudiarta1, L. Sahrul Hudha1 \\ ${ }^{I}$ Physics Department, Faculty of Mathematics and Natural Sciences, Universitas Mataram. Mataram. West Nusa Tenggara, \\ Indonesia
}

DOI: https://doi.org/10.29303/jpmpi.v3i2.570

Sitasi:. Kurniawidi, D. W., Ardianto, T., Syamsuddin, Sudiarta, I. W., \& Hudha, L. S. (2020). Artikel Ilmiah Sebagai Media Kenaikan Pangkat Guru MA - MTs di Pondok Pesantren Darul Aminin NW Aikmual Praya Lombok Tengah. Jurnal Pengabdian Magister Pendidikan IPA, 3(2)

\author{
Article history \\ Received: 25 Oktober \\ Revised: 15 Nopember \\ Accepted: 29 Desember \\ *Corresponding Author: Dian \\ W. Kurniawidi, Physics \\ Department, Faculty of \\ Mathematics and Natural \\ Sciences, Universitas Mataram. \\ Mataram. West Nusa Tenggara, \\ Indonesia \\ Email: \\ diankurnia@unram.ac.id
}

\begin{abstract}
Research activities, such as scientific writing, in schools have never been prioritized to be carried out, even though the government has carried out various trainings to improve teachers' writing competencies. Writing scientific papers is also defined as a condition for teachers' rank. Related to these problems, this Community Service activity aims to: (1) Know the understanding of teachers in terms of scientific writing, (2) Provision of scientific work guidance (3) Knowing the competence of presenters related to scientific writing material. This activity was attended by all teachers at the Darul Aminin Islamic Boarding School Foundation, NW Aikmual Praya, Central of Lombok. Participants consisted of Madrasah Tsanawiyah Teachers and Madrasah Aliyah Teachers at the PP Darul Aminin Foundation. Based on the results of the questionnaire stated that $82 \%$ of participants wanted structured guidance, the material presented met the required criteria as much as $84 \%$ and the presenters had professional abilities of $99 \%$. It is planned to hold virtual classes using UNRAM's moodle LMS as a follow-up step of this activity.
\end{abstract}

Keywords: Scientific writing; Teacher's competencies; Virtual classes

\section{Pendahuluan}

Publikasi ilmiah merupakan salah satu unsur dari pengembangan diri yang memiliki angka kredit. Nilai angka kredit ini sangat penting bagi guru dalam hal jabatan fungsional sebagai seorang pegawai negeri sipil. Jabatan fungsional merupakan jabatan yang mempunyai ruang lingkup tugas, tanggung jawab, dan wewenang untuk melakukan tugas utama menjadi seorang guru. Pada pasal 16 ayat (2) yang berlaku 1 Januari 2011 menyatakan "Untuk kenaikan jabatan/pangkat setingkat lebih tinggi dari guru pertama, pangkat penata muda, golongan ruang III/a sampai dengan guru utama, pangkat Pembina utama, golongan ruang IV/e wajib melakukan kegiatan pengembangan keprofesian yang meliputi pengembangan diri, dan/atau karya inovatif, sehingga guru-guru perlu menulis suatu karya ilmiah yang dipublikasikan dalam jurnal ilmiah untuk mengusulkan kenaikan jabatan.

Kenyataan di lapangan, sebagian besar guru yang berada di Lombok kesulitan dalam membuat artikel ilmiah. Bahkan banyak diantaranya asing dengan artikel ilmiah, padahal fokus kajian di tingkat sekolah menengah adalah tentang Penelitian Tindakan Kelas (PTK). Wardani (2008) menyatakan penelitian ini mengandalkan kegiatan pada Siklus Belajar mengikut 4 tahapan, yaitu Perencanaan (Planning), Pelaksanaan (Acting), Pengamatan (Observation), dan Refleksi 
(Reflection). Kejadian di kecamatan Labuapi, Lombok Barat menunjukkan eberapa guru diantaranya pernah memiliki tulisan PTK, karena tidak ada media konsultasi dan media yang dituju menyebabkan $95 \%$ guru di kecamatan Labuapi tidak dapat naik menuliskan karya tersebut dalam bentuk artikel (Dian Kurniawidi, 2015). Sebagian besar guru-guru di kecamatan Aikmual ini belum memahami hal-hal mendasar dalam menulis artikel ilmiah. Mulai dari tidak dapat membedakan antara karya tulis ilmiah dengan artikel ilmiah, tidak faham cara memperoleh refrensi, kesulitan dalam identifikasi topik, dan pemahaman peyusunan outline.

Kegiatan abdimas ini dilakukan untuk melakukan survei tentang pentingnya diadakan bimbingan penulisan karya ilmiah dan mengetahui tingkat pemahaman guru terhadap tahapan proses dalam PTK.

\section{Metode}

Tahapan ini dibagi menjadi 3 tahapan utama, yaitu: (1) Persiapan, tahap ini dilakukan identifikasi masalah, pemilihan sekolah sebagai target pelaksanaan kegiatan, wawancara dengan pihak sekolah terutama mengenai alokasi waktu pelaksanaan kegiatan karena akan melibatkan semua guru MA dan MTs yang mengajar di yayasan Pondok Pesantren Darul Aminin NW Praya. Pemilihan tempat dilaksakannya kegiatan abdimas ini cukup rumit mengingat kondisi wabah pandemi Covid_19 yang melanda seluruh wilayah di Indonesia. Adapun target peserta pelatihan yang direncanakan sejumlah 20 orang guru, meliputi guru seluruh mata pelajaran, tidak terbatas hanya untuk guru MIPA saja. (2) Pelaksanaan, kegiatan disepakati untuk dilaksanakan pada hari Rabu tanggal 30 September 2020, dari pukul $08.00-$ 14.30 WITA. Pada akhirnya kegiatan ini diikuti oleh seluruh guru di yayasan PP Darul Aminin NW Aikmual Praya, yang hadir berjumlah sekitar 18 orang guru dari 12 mata pelajaran. Kegiatan pada tahap ini adalah (a) penyampaian materi, (b) pelatihan dengan Lembar Kerja Guru. (c) pembahasan dan diskusi (3) Evaluasi, pada tahap ini disimpulkan kegiatan yang sudah dilakukan, diberikan angket sebagai indikator tujuan yang ingin dicapai dan pemberian umpan balik (4) Umpan Balik, diharapkan dapat dibuat sebuah kursus online yang diselenggarakan oleh
Universitas Mataram memanfaatkan moddle daring UNRAM.

\section{Hasil dan Pembahasan}

Peserta yang mengikuti kegiatan penulisan artikel ilmiah ini berasal dari disiplin ilmu yang berbeda-beda. Terdapat 12 kategori keilmuan yaitu Bahasa Inggris, Pend. Kewarganegaraan, IPA, IPS Sejarah, IPS Ekonomi, Matematika, Al Qur'an Hadits, Fiqih Islam, TIK, Bahasa Indonesia, Bimbingan Konseling dan Bahasa Arab. Dari 18 angket yang dibagikan kepada peserta, hanya 13 angket yang dikembalikan kepada Tim Pengabdian Kepada Masyarakat. Komponen yang diamati meliputi (1) Pemahaman terhadap Karya Ilmiah, (2) Rencana Kegiatan Pembimbingan, dan (3) Kompetensi Pemateri.

Hasil dari setiap aspek yang diamati dapat ditampilkan pada gambar (1), gambar (2) dan gambar (3).

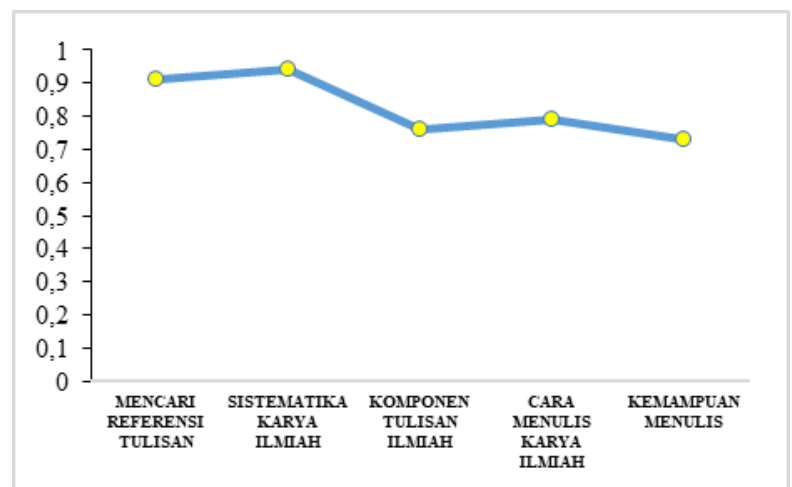

Gambar 1. Komponen Penilaian Persentase Pemahaman Karya Ilmiah

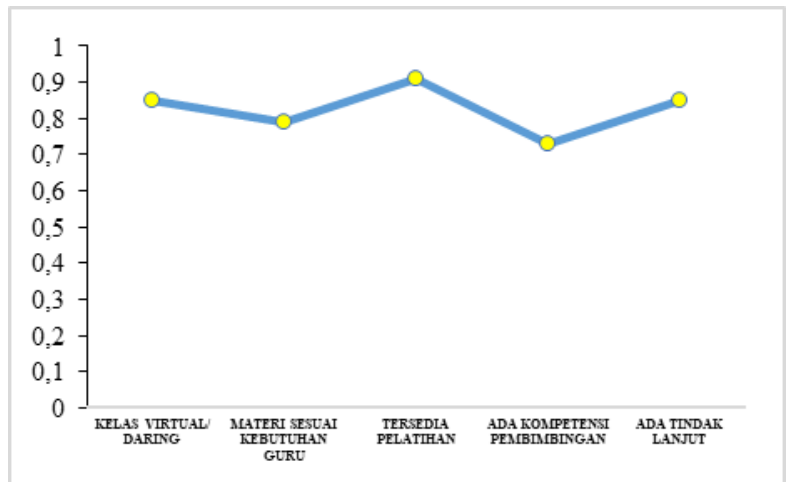

Gambar 2. Rencana Kegiatan Pembimbingan 


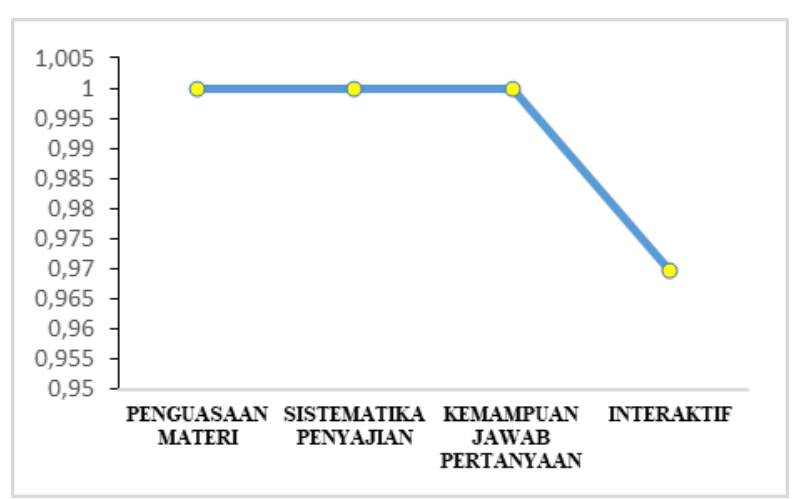

Gambar 3. Kompetensi Pemateri

Berdasarkan data pada gambar 1 dan gambar 2 diketahui bahwa mayoritas guru menghendaki ada pembimbingan secara rutin dan ada kegiatan pelatihan. Tidak dipilih apakah dilakukan secara daring ataupun pembimbingan langsung. Keduanya mendapatkan respon yang sama baiknya. Apabila dinyatakan dalam rerata perolehan persentase diketahui bahwa $82 \%$ guru menghendaki adanya kegiatan pembimbingan. Materi yang disajikan telah memenuhi kriteria yang dibutuhkan sebesar $84 \%$. Berdasarkan gambar 3 dapat dilihat bahwa menurut audiens kemampuan pemateri sebesar $99 \%$.

Berdasarkan hasil kerja LKS, dari 13 pekerjaan yang dikembalikan kepada Tim Pengabdian Masyarakat, diketahui penguasaan materi prapelatihan Penelitian Tindakan Kelas baru sekitar 69\%. Hal ini berarti sebagian besar guru sebenarnya memang belum memahami materi dengan baik. Dokumentasi pelaksanaan kegiatan abdimas ditampilkan pada gambar 4. Gambar 4(a) menampilkan kegiatan penyampaian materi dan gambar 4(b) menunjukkan pelaksanaan pengisian Lembar Kerja Guru.

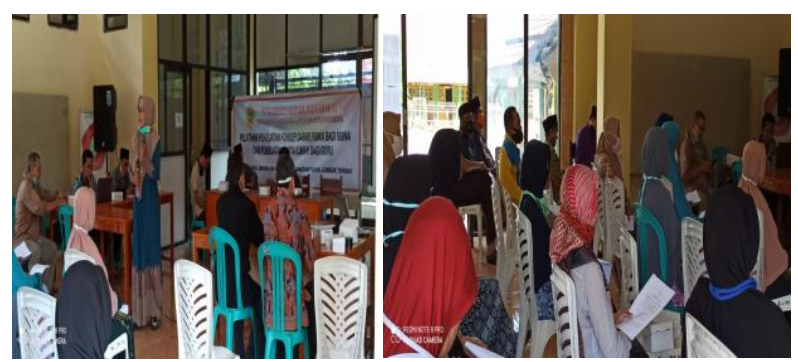

Gambar 4. Penyampaian Materi dan Pelaksanaan Kegiatan

Dalam kenyataannya pada dunia pendidikan dasar dan menengah, guru mayoritas lebih sibuk menyiapkan siswa siswinya untuk menghadapi Ujian Akhir. Peningkatan kompetensi guru tidak menjadi prioritas. Terdapat beberapa guru yang mampu menempuh kenaikan pangkatnya tetapi pada umumnya penelitian tidak dikerjakan sediri tetapi dibantu oleh pihak lain, sehingga guru yang bersangkutan tidak mampu memberikan pengarahan kepada rekan lainnya.

\section{Kesimpulan}

Berdasarkan kegiatan yang telah dilakukan maka dapat disimpulkan hasil dari kegiatan ini adalah:

1. Pemahaman guru terhadap tahapan dalam melakukan penulisan ilmiah, khususnya dalam melakukan kegiatan Penelitian Tindakan Kelas (PTK) sebesar 69\%.

2. Respon guru apabila diadakan kegiatan pembimbingan Karya Ilmiah, baik berupa pembimbingan secara daring atau pembimbingan secara langsung sebesar $82 \%$.

3. Kompetensi pemateri dalam menjelaskan materi sesuai dengan harapan guru sebesar $99 \%$ dan materi yang dijelaskan telah bersesuaian dengan kebutuhan sebesar $84 \%$.

\section{Saran}

Saran untuk kegiatan abdimas ini adalah segera menginisiasi kelas daring penyusunan karya ilmiah memanfaatkan daring UNRAM. Kegiatan ini diharapkan dapat disosialisasikan kepada seluruh guru di propinsi NTB sebagai salah satu wujud kontribusi UNRAM terhadap dunia pendidikan.

\section{Ucapan Terima Kasih}

Terimakasih penulis sampaikan kepada LPPM Universitas Mataram yang telah memberikan dana PNBP Tahun Anggaran 2020 nomor kontrak 2271/UN18/LPPM/2020 sehingga kegiatan Pengabdian kepada Masyarakat kali ini dapat terlaksana tepat waktu dan mendapatkan hasil sesuai yang diharapkan.

\section{Daftar Pustaka}

Anonim. 2020. Panduan Kegiatan Penelitian dan Pengabdian Kepada Masyarakat Tahun 2020. Universitas Mataram.

Anonim. 2019. Buku 4 Pengembangan Keprofesian Berkelanjutan Edisi Revisi 2019. 
Kementrian Pendidikan dan Kebudayaan. Jakarta.

Dian W. Kurniawidi, Siti Alaa', Susi Rahayu, I Wayan Sudiarta. 2015. Workshop Penulisan Artikel Ilmiah bagi Guru SMP se-Kecamatan Labuapi Lombok Barat. Laporan Pengabdian. Dibiayai Dana BOPTN. Universitas Mataram: Mataram NTB.

Juknis Pelaksanaan Angka Kredit Bagi Jabatan Guru, dikutip dari Kepmendikbud No.02/O/1995: 44-45).

Kunandar, 2011. Langkah Mudah Penelitian Tindakan Kelas, Jakarta : PT. Rajawali Pers

Peraturan Menteri Negara Pendayagunaan Aparatur Negara Nomor 16 Tahun 2009 tentang Jabatan Angka Fungsional Guru dan Angka Kreditnya.

Tanjung, H. B. N. \& Ardial, H. 2010. Pedoman penulisan karya ilmiah dan mempersiapkan diri menjadi penulis artikel ilmiah. Jakarta: Prenada Media Group.

Wardhani, I.G.A.K. dkk. (2008). Penelitian Tindakan Kelas. Jakarta : Universitas Terbuka 